\title{
TRITERPENE GLYCOSIDES OF GLEDITSCHIA TRIACANTHOS
}

\author{
T. A. Ali-zade, E. S. Kondratenko, and N. K. Abubakirov
}

Khimiya Prirodnykh Soedinenii, Vol. 6, No. 4, pp. 482-483, 1970

UDC $547.918+544.597$

We have studied the pericarp and seeds of the decorative tree Gleditschia triacanthos L. (common honeylocust) (family Leguminosae) for its content of triterpene glycosides. According to authors who have studied this plant previously, the sugar moiety of the glycosides includes glucose and fructose $[1,2]$.

In our experiments, the seeds contained only traces of triterpene glycosides and therefore we have not considered them in detail. The dried pericarp (pods) of the gleditschia were exhaustively extracted with hot methanol. When the methanolic extract was chromatographed in a thin layer of silica gel (KSK) in the systems 1) butan-1-olethanol-25\% ammonia $(10: 2: 5), 2)$ butan-1-ol-acetic acid-water $(4: 1: 5)$, and 3) chloroform-methanol-water $(65: 35: 10)$, no less than four compounds of a glycoside nature were detected, and they have been called, in order of increasing polarity, triacanthosides $\mathrm{A}, \mathrm{B}, \mathrm{C}$, and D. Glycosides B and C were present in approximately equal amounts and formed the bulk of the combined glycosides.

The methanolic extract was dissolved in water and extracted with butanol. The evaporated butanol extracts were chromatographed on a column of silica gel (KSK) in system 1 . This gave a mixture of glycosides and an individual crystalline substance with $\mathrm{mp} 169-170^{\circ} \mathrm{C}$ (from methanol), $[\alpha]_{\mathrm{D}}^{20}+65^{\circ}$ (water), which proved to be sucrose.

The mixture of glycosides was hydrolyzed by heating with $5 \% \mathrm{H}_{2} \mathrm{SO}_{4}$. The resulting precipitate was chromatographed on a column of KSK silica gel in a chloroform-ethanol (25:2) mixture (system 4). This gave oleanolic acid with $\mathrm{mp} 300-305^{\circ} \mathrm{C},[\alpha]_{\mathrm{D}}^{20}+80^{\circ}$ (c 1.64, chloroform) and echinocystic acid with $\mathrm{mp} 305-306^{\circ} \mathrm{C}$, $[\alpha]_{D}^{20}+33^{\circ}$ (c 1.5 , chloroform). Both compounds were identified by thin-layer chromatography in several systems and by mixed melting points with authentic samples. The same aglycones have been observed previously in the glycosides of Gleditschia fera Merr [3].

The hydrolysate of the mixture of glycosides was shown by paper chromatography in system 2 to contain four sugars: D-glucose, L-arabinose, D-xylose, and L-rhamnose.

Thus, statements that fructose is present in the triterpene glycosides of gleditschia [1,2] are erroneous and are apparently due to inadequate separation of the glycosides from sucrose.

The mixture of glycosides freed from glucose was rechromatographed on a column of silica gel in system 3. Pure crystalline triacanthoside $\mathrm{C}$ was isolated with $\mathrm{mp} 230-234^{\circ} \mathrm{C}$ (decomp), $[\alpha]_{\mathrm{D}}^{20}-14.4^{\circ}$ (c 0.79 , $70 \%$ methanol).

The hydrolysis of triacanthoside $\mathrm{C}$ with $5 \% \mathrm{H}_{2} \mathrm{SO}_{4}$ gave oleanolic acid and the sugars $\mathrm{D}$-glucose, L-arabinose, D-xylose, and L-rhamnose, which were identified by direct comparison with authentic samples.

\section{RE FERENCES}

1. E. Z, Asoeva, E. K. Denisova, A. D. Dauksha, and D. A. Murav'eva, Uchen. zap. Pyatigorskogo farm. instituta, 6, no. 1, 11-13, 1967.

2. I. T. Tairov, Azerb. med. zh., no. 8, 35, 1965.

3. Nguen Dang Täm, C. R. Acad. sci., 264, no. 1, 121-124, 1967.

16 March 1970

Institute of the Chemistry of Plant Substances, AS UzSSR 